\title{
PENINGKATAN KEMAMPUAN MAHASISWA MEMAHAMI STRUKTUR WACANA MELALUI METODE ANALISIS WACANA KRITIS BERBASIS LITERASI MEDIA SOSIAL
}

\author{
Cecep Dudung Julianto \\ Institut Pendidikan Indonesia (IPI) Garut \\ cecepdudung@institutpendidikan.ac.id
}

\begin{abstract}
ABSTRAK
Di era literasi media modern saat ini, pesan media mempunyai peran yang sangat kuat dalam membentuk perilaku masyarakat. Derasnya informasi yang beredar di masyarakat belum diimbangi dengan keterampilan berpikir kritis dan literasi media sosial. Kesalahan dalam menafsirkan sebuah wacana teks berita dapat menimbulkan 'krisis komunikasi' dengan menyebarkan informasi yang salah secara cepat. Keterampilan mahasiswa berpikir kritis dan memahami struktur teks wacana sangat penting untuk mendukung prinsip belajar sepanjang hayat dan sebagai bagian pembelajaran kepada warga negara. Penerapan metode analisis wacana kritis berbasis literasi media sosial dapat dijadikan solusi untuk meningkatkan kualitas mahasiwa dalam memahami struktur wacana, misalnya: mengklasifikasikan bagianpendahuluan, isi, dan penutup serta menganalisis kode media dan kompetensi untuk menafsirkan beberapa makna dan pesan teks berita sehingga mahasiswa dapat mengevaluasi pesan wacana tersebut. Metode penelitian yang digunakan yaitu eksperimen sejati dengan desain Pretest-Posttest Control Group Design. Teknik pengumpulan yang digunakan yaitu tes, observasi, walkthrough, wawancara, dan angket. Hasil penelitian menunjukkan bahwa: 1) profil kemampuan mahasiswa memahami struktur wacana sebagian besar berada pada kategori sedang 38,5\%, dengan rentang skor 50-69. Kelas eksperimen dan kelas kontrol memiliki kemampuan awal yang sama; 2) penggunaan metode analisis wacana kritis berbasis literasi media sosial mampu meningkatkan kemampuan mahasiswa memahami struktur wacana secara signifikan daripada metode pembelajaran konvensional.
\end{abstract}

Kata kunci: Struktur Wacana, Metode Analisis, Literasi Media Sosial

\section{A. PENDAHULUAN}

Distribusi wacana ke tengah masyarakat pada era post-modern ini, dilaksanakan secara strategis melalui berita daring. Mayoritas masyarakat mengetahui informasi seluruh ranah kehidupan dari media massa, baik media lokal, regional, nasional, bahkan internasional. Berbagai informasi media selama ini membanjiri masyarakat dengan sifatnya yang mudah dan murah untuk diakses.

Perkembangan ini mengubah dominasi media cetak ke media daring. Wacana yang hadir di tengah masyarakat pun kian beragam. Berbeda dengan era Orde Baru, isi pemberitaan media sekarang lepas dari kontrol dan monopoli sehingga para pemilik media mempunyai keleluasaan untuk 


\section{DEIKSIS - JURNAL PENDIDIKAN BAHASA DAN SASTRA INDONESIA}

memproduksi berita. Beberapa tahun terakhir, banyak perusahaan berita daring banyak menggunakan media sosial sebagai alat untuk menyebarluaskan berita-beritanya.

Permasalahan utama yang timbul yaitu independensi media dalam pemberitaan daring dan propaganda pemilik media yang bertujuan untuk mendapatkan keuntungan yang disebarluaskan dengan mudah melalui media sosial. Berita ini tidak bebas nilai atau tidak netral tetapi sarat akan pertarungan ideologi. Secara negatif, ideologi dilihat sebagai suatu kesadaran palsu, yaitu suatu kebutuhan untuk melakukan penipuan dengan cara memutarbalikkan pemahaman orang mengenai realitas sosial.

Pernyataan-pernyataan di atas semakin menegaskan pentingnya pengkajian berita daring di media sosial dengan menggunakan analisis wacana yang sesuai dengan karakteristik kebutuhan pengguna dan perkembangan media di era sekarang mengingat pesan media mempunyai peran yang sangat kuat dalam membentuk perilaku masyarakat (Severin \&Tankard, 2005). Dengan demikian, penggunaan metode analisis wacana kritis berbasis literasi media sosial ini dapat disesuaikan dengan kebutuhan mahasiswa. Bukan hanya untuk meningkatkan kompetensi berwacana mahasiswa dari aspek bahasa, tetapi meningkatkan kemampuan mahasiswa untuk menangkap pesan wacana dengan pemikiran kritis sehingga mampu memiliki kemampuan literasi media sesuai tujuan pembelajaran literasi media.

Kemampuan ini dapat mendukung prinsip belajar sepanjang hayat dan sebagai bagian pembelajaran terhadap warga negara dalam memahami sebuah pesan teks berita. Berdasarkan uraian di atas, penelitian ini bertujuan untuk mengetahui profil kemampuan mahasiswa memahami struktur wacana dan untuk mengetahui efektivitas penggunaan metode analisis wacana kritis berbasis literasi media sosial dalam pembelajaran struktur wacana.

\section{B. KAJIAN TEORETIS}

Media sosial ini menjadi 'bom waktu' karena dapat menimbulkan 'krisis komunikasi' dengan menyebarkan informasi yang salah secara cepat. Dengan begitu, media sosial dapat digunakan sebagai alat untuk 'menyakiti' individu atau kelompok. Hal ini berpotensi menciptakan risiko krisis dan konflik bagi individu, organisasi atau kelompok, dan para stakeholder, (FearnBanks, 2001 dan River et al, 2012, hlm. 27).

Wacana selalu mempunyai kepentingan tertentu yang bersifat mengarahkan, memengaruhi, melegitimasi, menilai, dan mengubah cara pandang pembaca melalui ideologi yang digunakan oleh pihak-pihak yang terlibat dalam proses rekonstruksi wacana, (Fairclough, 1995; Wodak, 2001; dan van Dijk, 2002). Oleh sebab itu, dari sudut pandang ini wacana dianggap tidak hanya aspek linguistik saja, tetapi lebih dari itu ada unsur nonlinguistik yang berupa ideologi, sosiokultural, histori, dan konteks sosial.

Di era literasi media modern saat ini, mahasiswa diwajibkan mempunyai kompetensi keberwacanaan. Untuk memperoleh keompetensi ini, mahasiswa harus memahami struktur wacana sebuah teks berita yaitu struktur makro, 
superstruktur, dan struktur mikro. Dengan demikian, mereka akan mampu untuk menganalisis kode media dan konvensi, kemampuan untuk mengkritisi nilai-nilai yang dominan, ideologi, dan kompetensi untuk menafsirkan beberapa makna dan pesan yang sampaikan oleh media. Selanjutnya, mereka dapat mengevaluasi pesan wacana tersebut. Untuk membangun masyarakat ini, pendidikan literasi media kritis harus diterapkan dalam satuan pendidikan untuk semua kalangan masyarakat pengguna bahasa.

\section{METODOLOGI}

Metode penelitian yang digunakan pada penelitian ini yaitu eksperimen sejati dengan desain Pretest-Posttest Control Group Design. Adapun populasi pada penelitian ini yaitu mahasiswa Program Studi Pendidikan Bahasa dan Sastra Indonesia tingkat III IPI Garut tahun akademik 2017-2018 yang berjumlah 73 orang.

Dari populasi tersebut diambil sampel dengan teknik sampel acak berdasarkan kelompok kelas menengah dan kelas bawah dengan jumlah 52 orang. Kemudian dibagi menjadi dua kelas, masing-masing kelas berjumlah 26 orang. Teknik pengolahan data dalam penelitian ini menggunakan statistic uji Mann-Whitney. Teknik pengumpulan data yang digunakan yaitu tes, observasi, walkthrough, wawancara, dan angket.

\section{PEMBaHASAN}

\section{Profil Kemampuan Mahasiswa Memahami Struktur Wacana}

Profil pemahaman mahasiswa pada pembelajaran struktur wacana dapat dilihat pada tabel berikut.

\section{Tabel 1}

Profil Kemampuan Mahasiswa Memahami Struktur Wacana

\begin{tabular}{|l|l|l|l|}
\hline Skor & Jumlah & Persentase & Kualifikasi \\
\hline$\geq 70$ & 26 & $33 \%$ & Tinggi \\
\hline $69-50$ & 30 & $38,5 \%$ & Sedang \\
\hline$<50$ & 22 & $28,2 \%$ & Rendah \\
\hline
\end{tabular}

Tabel di atas menunjukkan bahwa pemahaman mahasiswa terhadap struktur wacana teks berita daring secara umum tergolong kategori 'sedang' dengan skor yang berkisar pada rentang 50-69, sedangkan sisanya tergolong kategori rendah dan tinggi. Studi awal ini diungkapkan sebagai gambaran untuk mengetahui kekurangan maupun kebutuhan untuk dikembangkan dalam penelitian. Selain itu, berdasarkan hasil wawancara dan observasi, pembelajaran struktur wacana selama ini mahasiswa kurang aktif dan kesulitan untuk memahami struktur wacana. Kekurangaktifan mereaksi atau merespons bacaan dalam menyampaikan ide atau gagasan dan pendapat, kesulitan menguraikan struktur wacana, dan menyimpulkan bacaan/teks berita berdasarkan fakta penunjang. 
2. Efektivitas Penggunaan Metode Analisis Wacana Kritis Berbasis Literasi Media Sosial dalam Meningkatkan Kemampuan Memahami Struktur Wacana

Tujuan dari penelitian ini adalah untuk mengetahui ada tidaknya perbedaan pemahaman sebelum pembelajaran antara kelas eksperimen dan kelas kontrol dan ada tidaknya perbedaan efektivitas penggunaan metode pembelajaran terhadap tingkat pemahaman struktur wacana antara kelas eksperimen dan kelas kontrol.

Untuk mengetahui ada tidaknya perbedaan pemahaman struktur wacana sebelum pembelajaran struktur wacana menggunakan uji Mann Whitney melalui program SPSS versi 20.0. Kriteria pengujian adalah nilai signifikansinya ( $\mathrm{Sig}$ ) lebih besar dari $\alpha(0,05)$ maka $\mathrm{H}_{0}$ diterima. Hasil analisis data dapat dilihat pada tabel berikut ini.

\section{Tabel 2}

Hasil Uji Kesamaan Rataan Skor Prates Pemahaman Struktur Wacana

\begin{tabular}{|c|c|c|}
\hline Statistik & Nilai & Keterangan \\
\hline $\begin{array}{l}\text { Mann Whitney } \\
\text { U }\end{array}$ & 271,5 & \multirow{3}{*}{ Ho Diterima } \\
\hline Z & $-1,252$ & \\
\hline $\begin{array}{l}\text { Asymp.Sig } \quad(2- \\
\text { Tailed) }\end{array}$ & 0,211 & \\
\hline
\end{tabular}

Dari hasil pengujian diatas terlihat bahwa nilai signifikansinya (Sig) sebesar 0,211 . Nilai signifikansi tersebut lebih besar dari $\alpha(0,05)$ maka $\mathrm{H}_{0}$ diterima, dengan demikian diperoleh hasil bahwa tidak terdapat perbedaan pemahaman mahasiswa sebelum pembelajaran pada kelas eksperimen dan kelas kontrol. Untuk menguji perbedaan efektivitas penggunaan metode pembelajaran terhadap peningkatan pemahaman struktur wacana setelah pembelajaran antara kelas eksperimen dan kelas kontrol digunakan uji Mann Whitney.

Tabel 3

Hasil Uji Dua Rata-Rata Skor Postest Pemahaman Mahasiswa

\begin{tabular}{|l|l|l|}
\hline Statistik & Nilai & Keterangan \\
\hline $\begin{array}{l}\text { Mann Whitney } \\
\text { U }\end{array}$ & 46,5 & \\
\hline Z & -538 & Ho Diterima \\
\cline { 1 - 1 } $\begin{array}{l}\text { Asymp.Sig (2- } \\
\text { Tailed) }\end{array}$ & 0,000 & \\
\hline
\end{tabular}

Dari hasil pengujian diatas terlihat bahwa nilai sig. Sebesar 0,000 . Nilai tersesbut lebih kecil dari taraf signifikansi $\alpha=0,05$ sehingga $\mathrm{H}_{0}$ ditolak dan $\mathrm{H}_{1}$ diterima sehingga dapat diperoleh hasil bahwa terdapat perbedaan efektivitas penggunaan metode analisis wacana kritis berbasis literasi media sosial dengan penggunaan metode pembelajaran konvensional untuk meningkatkan pemahaman mahasiswa pada mata kuliah tatawacana.

Untuk mendukung dan mengetahui efektivitas metode analisis wacana kritis berbasis literasi media sosial dalam meningkatkan pemahaman mahasiswa pada pembelajaran struktur wacana dapat dilihat dari peningkatan sebelum dan sesudah pembelajaran diukur dengan nilai gain ternormalisasi ( $N$-Gain). Berikut ini adalah perbandingan nilai $\mathrm{N}$-Gain dan nilai rata-rata pemahaman yang diperoleh mahasiswa sebelum dan sesudah pembelajaran. 
Tabel 4

\section{Hasil Indeks Gain Kelas Eksperimen dan kontrol}

\begin{tabular}{|r|c|c|c|c|}
\hline Kelas & Pretest & Posttest & $\langle g>$ & $\begin{array}{r}\text { Kriteri } \\
\text { a }\end{array}$ \\
\hline $\begin{array}{l}\text { Eksperim } \\
\text { en }\end{array}$ & $\mathbf{5 4 , 7 7}$ & $\mathbf{7 9 , 9 6}$ & $\mathbf{0 , 6 3}$ & Sedang \\
\hline Kontrol & $\mathbf{3 9 , 9 6}$ & $\mathbf{6 1 , 1 9}$ & $\mathbf{0 , 3 1}$ & Sedang \\
\hline
\end{tabular}

Efektivitas peningkatan pemahaman mahasiswa pada kelas eksperimen dapat dilihat dari peningkatan nilai rata-rata pemahaman yang dicapai mahasiswa setelah pembelajaran. Jika sebelumnya nilai rata-rata mahasiswa sebesar 54,77 meningkat menjadi 79,96, dengan nilai N-Gain untuk peningkatan pemahaman pada kelas eksperimen sebesar 0,63 yang dikategorikan peningkatan sedang.

Adapun pada kelas kontrol rata-rata pretes adalah 39,96, setelah pembelajaran dengan metode konvensional terjadi peningkatan rata-rata (postest) menjadi 61,19.Tetapi peningkatan tersebut masih lebih rendah dibandingkan dengan peningkatan pada kelas eksperimen. Hal ini ditunjukkan dari nilai $\mathrm{N}$-Gain pada kelas kontrol hanya sebesar 0,31 yang terkategori peningkatan sedang.

Hasil tersebut di atas dapat dibuktikan melalui pengujian secara statistik dengan bantuan SPSS 20.0 melalui uji statistik parametrik dengan uji dua rata-rata menggunakan uji $t$ dengan statistik Independent Sample T-Test. Bersadarkan hasil uji statistiknya dapat disimpulkan pada tabel berikut ini.
Tabel 5

Hasil Uji Dua rata-rata Skor $N$-Gain Pemahaman Struktur Wacana Mahasiswa

\begin{tabular}{|l|l|l|}
\hline Statistik & Nilai & Keterangan \\
\hline $\begin{array}{l}\text { t-tes (Equal } \\
\text { Variances } \\
\text { assumed) }\end{array}$ & 6,832 & Ho Ditolak \\
\hline Df & 50 & \\
\hline $\begin{array}{l}\text { Asymp.Sig (2- } \\
\text { Tailed) }\end{array}$ & 0,00 & \\
\hline
\end{tabular}

Berdasarkan tabel diatas dapat diketahui nilai Sig $=0,00<\alpha=0,05$ maka $\mathrm{H}_{0}$ ditolak dan $\mathrm{H}_{\mathrm{a}}$ diterima artinya efektivitas penggunaan metode analisis wacana kritis berbasis literasi media sosial di kelas eksperimen lebih tinggi daripada kelas kontrol yang menggunakan media pembelajaran konvensional dalam meningkatkan pemahaman struktur wacana mahasiswa. Jadi, penggunaan metode analisis wacana kritis berbasis literasi media sosial memberikan peningkatan yang lebih baik dibandingkan metode pembelajaran secara konvensional.

Pada pembahasan ini akan diuraikan hasil penelitian peningkatan kemampuan mahasiswa struktur wacana melalui penggunaan metode analisis wacana kritis berbasis literasi media sosial. Pembelajaran sttruktur wacana berisi sejumlah konsep yang harus dikuasai dan dipahami oleh mahasiswa. Mahasiswa diminta untuk mengetahui konsep struktur sebuah wacana melalui hubungan antarbagian wacana dengan menguraikan bagian pendahuluan, isi, dan penutup. 


\section{DEIKSIS - JURNAL PENDIDIKAN BAHASA DAN SASTRA INDONESIA}

Melalui hubungan tersebut di atas, mahasiswa dapat menjelaskan struktur makro atau tematik, superstruktur atau skema sebuah wacana, dan struktur mikro. Struktur terakhir mencakup penggunaan aspek sintaksis, semantik, stilistik, dan retoris. Seluruh aspek ini akan membantu mahasiswa memahami pesan sebuah wacana, baik tersurat maupun tersirat. Pemahaman konsep wacana sangat penting, karena dengan penguasaan konsep akan memudahkan mahasiswa dalam mempelajari materi struktur wacana. Pada setiap pembelajaran diusahakan lebih ditekankan pada penguasaan konsep agar mahasiswa memiliki bekal dasar yang baik untuk mencapai kemampuan dasar yang lain seperti penalaran, komunikasi, koneksi dan pemecahan masalah.

Tujuan dari penelitian ini adalah untuk mengetahui peningkatan pemahaman mahasiswa dengan menggunakan metode analisis wacana kritis berbasis literasi media sosial. Penelitian ini diharapkan dapat membantu para mahasiswa dalam meningkatkan kemampuan pemahaman struktur wacana sehingga mahasiswa dapat mengidentifikasi struktur dan makna pesan wacana berlandaskan berpikir kritis. Langkah yang dilakukan setelah pengambilan data adalah pengolahan data dengan menggunakan analisis data pretes, postes, dan N-Gain tingkat pemahaman mahasiswa. Setelah penelitian dilakukan maka diperoleh data yang berbentuk skor mahasiswa dari instrument soal yang diujikan kepada mahasiswa. Dari data yang terkumpul dilakukan pengolahan dan analisis data pretes, postes, dan N-Gain pemahaman mahasiswa.

Dari hasil analisis skor pretes diperoleh kesimpulan bahwa pemahaman awal mahasiswa dari kelas kontrol maupun kelas eksperimen adalah sama. Hal itu dibuktikan dengan nilai signifikansi nilai sig $0,211>$ dari $\alpha(0,05)$ maka Ho diterima. Hal ini dapat diartikan bahwa tidak terdapat perbedaan rataan skor pretes pemahaman mahasiswa pada kelas kontrol dan kelas eksperimen. Dengan tidak adanya perbedaan ini maka menandakan bahwa kemampuan awal dari kelas kontrol dan kelas eksperimen adalah sama. Kondisi awal mahasiswa seperti ini sangat mendukung peneliti untuk memberikan perlakuan yang berbeda kepada kelas eksperimen dan kelas kontrol dalam pembelajaran struktur wacana sehingga dapat diketahui apakah efektivitas penggunaan metode analisis wacana kritis berbasis literasi media sosial untuk meningkatkan pemahaman mahasiswa pada pembelajaran struktur wacana lebih tinggi daripada pemahaman mahasiswa yang menggunakan metode pembelajaran secara konvensional.

Dari hasil pengujian hipotesis terhadap skor postes pemahaman didapat nilai $\mathrm{Sig}=$ $0,000<\alpha=0,05$ maka $\mathrm{H}_{0}$ ditolak dan $\mathrm{H}_{\mathrm{a}}$ diterima artinya terdapat perbedaan efektivitas penggunaan metode analisis wacana kritis berbasis literasi media sosial dengan penggunaan metode pembelajaran konvensional untuk meningkatkan pemahaman mahasiswa pada mata kuliah tatawacana. Adapun dapat diketahui bahwa rata-rata skor pretest dan posttest pada kelas eksperimen adalah 54,77 dan 79,96 dengan 


\section{DEIKSIS - JURNAL PENDIDIKAN BAHASA DAN SASTRA INDONESIA}

pencapaian nilai rata-rata postes diatas KKM yaitu $\geq 70$ sebesar $88,5 \%$. Sedangkan pada kelas kontrol diketahui rata-rata skor pretest dan posttest adalah sebesar 39,96 dan 61,19 dengan pencapaian nilai rata-rata postes dibawah KKM yaitu $\geq 70$. Dari data tersebut terlihat bahwa terdapat peningkatan pemahaman mahasiswa pada kelas eksperimen dan kontrol.

Kemudian untuk mengetahui keefektifan penggunaan metode analisis wacana kritis berbasis literasi media sosialpada kelas eksperimen dan penggunaan media pembelajaran konvensional juga digunakan perhitungan gain ternormalisasi berdasarkan data nilai pretest dan posttest pada kelas eksperimen, diperoleh nilai gain ternormalisasi kelas eksperimen sebesar 0.56 dan kelas kontrol sebesar 0.35 . Nilai tersebut diinterpretasikan ke dalam kriterium nilai $\langle g\rangle$, diperoleh efektivitas metode analisis wacana kritis berbasis literasi media sosial untuk meningkatkan pemahaman mahassiswa di kelas eksperimen dan kontrol tergolong sedang. Dari hasil pengujian statistik N-Gain diperoleh nilai Sig $=0,00<$ $\alpha=0,05$ maka $\mathrm{H}_{0}$ ditolak dan $\mathrm{H}_{\mathrm{a}}$ diterima artinya nilai $\mathrm{Sig}=0,016<\alpha=0,05$ maka $\mathrm{H}_{0}$ ditolak dan $\mathrm{H}_{\mathrm{a}}$ diterima artinya efektivitas penggunaan metode analisis wacana kritis berbasis literasi media social di kelas eksperimen lebih tinggi daripada kelas kontrol yang menggunakan media pembelajaran konvensional dalam meningkatkan pemahaman mahasiswa.

Berdasarkan hasil penelitian yang dilakukan pada setiap pertemuan, di kelas eksperimen mahasiswa dituntut untuk dapat berperan lebih aktif dalam memperoleh kesempatan membangun sendiri pengetahuannya sehingga memperoleh pemahaman yang mendalam serta dalam proses pembelajarannya lebih bervariatif. Berdasarkan hasil observasi dan angket, peningkatan hasil belajar yang diraih oleh kelas eksperimen dikarenakan adanya suasana belajar di kelas yang lebih kondusif, aktif dan minat serta antusias mahasiswa sangat terlihat dibandingkan pada kelas kontrol, terutama pada hal distribusi materi pembelajaran yang tidak terpusat hanya pada guru.

Budaya belajar yang dikembangkan di kelas eksperimen melalui penggunaan metode analisis wacana kritis berbasis literasi media sosial adalah keaktifan siswa dalam membangun sendiri keingintahuannya, membangun karakter keinginan membantu teman yang kesulitan, serta pemanfaatan waktu yang bisa optimal di kelas karena kegiatan sudah terstruktur. Dalam proses pembelajarannya, dosen bersifat sebagai fasilitator, sehingga mahasiswa lebih leluasa untuk mengkontruksi kemampuan pemahaman konsepnya sesuai dengan rangsangan dari metode yang dipelajarinya. Meningkatnya keaktifan mahsiswa, baik dalam hal bertanya maupun mempresentasikan tugas yang telah diselesaikannya. Kelebihan lainnya adalah tugas mahasiswa menjadi lebih variatif dan kreatif karena siswa memiliki metode khusus dalam menganalisis struktur wacana dibandingkan dengan siswa pada kelas kontrol yang menggunakan metode konvensional. 


\section{E. SIMPULAN}

Berdasarkan hasil penelitian dan pembahasan di atas, peneliti dapat membuat simpulan sebagai berikut ini.

1) Profil kemampuan mahasiswa memahami struktur wacana sebagian besar berada pada kategori sedang dengan rentang skor 50-69. Mahasiswa kelas eksperimen dan kelas kontrol memiliki kemampuan awal yang sama dalam pembelajaran struktur wacana.

2) Efektivitas penggunaan metode analisis wacana kritis berbasis literasi media sosial dalam meningkatkan kemampuan memahami struktur wacana mahasiswa kelas eksperimen lebih tinggi daripada kelas kontrol yang menggunakan media pembelajaran konvensional

Dari simpulan di atas, peneliti dapat memberikan saran kepada dosen untuk menerapkan metode analisis wacana kritis berbasis literasi media sosial dalam pembelajaran tatawacana atau analisis wacana karena dapat meningkatkan kemampuan mahasiswa memahami struktur wacana. Selain itu, metode ini dapat digunakan dalam pembelajaran yang bertujuan untuk meningkatkan kemampuan berpikir kritis dan kreatif, dan menganalisis pesan atau makna yang terdapat pada sebuah wacana.

\section{F. DAFTAR PUSTAKA}

Akker, J.V. (1999). Desaign Approaches and Tool in Education and Training. London: Kluwer Academic Publishers.

Akker, J.V. (1999). Principles and Methods of Development Research. Diambil pada tanggal 2 Agustus 2010, dari http://projects.edte.utwente.nl/smarter net/

version $2 /$ cabinet/ico_design_principle s.pdf

Anshori, Dadang. (2011). "Peningkatan Kemampuan Berpikir Kritis Mahasiswa melalui Pendekatan Studi Wacana Berbasis Analisis Wacana Kritis (Critical Discourse Analysis)". Diterbitkan dalam Jurnal Wacana Pendidikan, STKIP Garut. Edisi 9 tahun ke-V Desember 2011.

Arikunto, S. (2006). Prosedur Penelitian: Suatu Pendekatan Praktik. Jakarta: Rineka Cipta.

Barve, G. (2016). Social Media and its Effects on Society. International Journal of School and Cognitive Psychology, Maret Vol. 3, Is. (1): 166.

Borg, W.R., \& Gall, M.D. (1989). Educational Research An Introduction $\left(5^{\text {th }} \mathrm{Ed}\right)$. New York: Longman.

Dudung, Cecep. (2013). "Representasi Ideologi Politik dalam Rubrik Berita Politik pada Surat Kabar Online. Diterbitkan dalam Jurnal Wacana Pendidikan, STKIP Garut. Edisi 13 tahun ke-VII Desember 2013.

Eriyanto. (2001). Analisis Wacana: Pengantar Analisis Teks Media. Yogyakarta: PT LKiS Pelangi Aksara Yogyakarta.

Eriyanto. (2011). Analisis Wacana: Pengantar Analisis Teks Media. Yogyakarta: PT LKiS Pelangi Aksara Yogyakarta. 


\section{DEIKSIS - JURNAL PENDIDIKAN BAHASA DAN SASTRA INDONESIA}

Fairclough, N. (1989a). Language and power. London: Longman.

Fairclough, N. (1992b). Discourse and social change. Cambridge: Polity Press.

Fairclough, N. (1995c). Critical Discourse Analysis: The critical study of language. New York: Longman.

Fairclough, Norman. (2003d). Relasi Bahasa, Kekuasaan, dan Ideologi. Terjemahan:Indah Rohmani. Gresik: Boyan Publishing.

Fowler, R., Hodge, B., Kress, G., \& Trew, T. (1979). Language \& control. London: Routledge \& Kegan Paul.

Fearn-Banks, K., (2001). Crisis communication: A review of some best practices. In R. L. Heath \& G. Vasquez (Eds.), Handbook of public relations (pp. 46-479). Thousand Oaks, CA: Sage.

Gall, M.D., Gall, J.P., \& Borg,W.R. (2003).

Educational Research An

Introduction.Seventh Edition. Boston:

Pearson Education Inc.

Hamad, Ibnu. (2007). Lebih Dekat dengan

Analisis Wacana. Tersedia pada:

http://ejournal.unisba.ac.id/index.php/ mediator/article/view/1252.Vol 8, No 2.

Hanae Ait Hattani. (2016). Media Literacy Education in English as a Foreign Language Classroom. International Journal of Media and Information Literacy, 2016, Vol. 1, Is. (2), pp. 108-115.

Jabbar, Ramdhani. (2017). Dewan Pers: Ada 2.000 Media Online, Hanya 211 yang Sesuai Kaidah Jurnalistik. Tersedia pada: http://news.detik.com/berita/3122996/ dewan-pers-ada-2000-media-onlinehanya-211-yang-sesuai-kaidahjurnalistik. 27 Maret 2017.

Karuchit, Warat. (2016). Negative Effects of Digital Media on Thai Youngsters: Case Studies from Thailand and Abroad. International Journal of Media and Information Literacy, 2016, Vol. 1, Is. (2), pp. 122-127.

Kellner, Douglas and Jeff Share. (2005).

Toward Critical Media Literacy: Core concepts, debates, organizations, and policy. Discourse: Studies in The Cultural Politics of Education Vol. 26, No. 3, September 2005, pp. 369-386.

Kemp, J.E., Morrison, G.R., \& Ross, S.M. (2003). Designing effective instruction $\left(2^{\text {nd }}\right.$ ed.). New York: John Wiley \& Sons.

Kress, G. (1985). Linguistic processes in socio-cultural practice. Geelong, Vic.: Deakin University Press.

Kress, G. \& Hodge, B. (1979/1993). Language as ideology. London: Routledge.

Lin, T.-B., Li, J.-Y., Deng, F., \& Lee, L. (2013). Understanding New Media Literacy: An Explorative Theoretical Framework. Educational Technology \& Society, 16 (4), 160-170.

Mulyana. (2005). Kajian Wacana : Teori, Metode dan Aplikasi Prinsip-Prinsip Analisis Wacana. Yogyakarta: Tiara Wacana. 
DEIKSIS - JURNAL PENDIDIKAN BAHASA DAN SASTRA INDONESIA

Mulyana, Deddy. (2010). Meodologi

Penelitian Kualitatif. Bandung: PT

Remaja Rosdakarya.

Nasution. (2003). Metode Penelitian

Naturalistik Kualitatif. Bandung:

Tarsito.

Oik, Yusuf . 2017. Jumlah Pengguna

Facebook di Indonesia Terus

Bertambah. Tersedia pada:

http://tekno.kompas.com/read/2016/10/

20/17062397/jumlah.pengguna.facebo

ok.di.indonesia.terus.bertambah. 27

Maret 2017 